\title{
Study the Interaction between Gold Nanoparticles and Bovine Serum Albumin: Spectroscopic Approach
}

Husain Alsamamra*, Ibrahim Hawwarin, Sawsan Abu-Sharkh and Musa Abuteir

Physics Department, Al-Quds University, Palestine

\begin{abstract}
Interaction between gold nanoparticles of 40 \& $60 \mathrm{~nm}$ with BSA has been investigated using UV-absorption spectrophotometry, fluorescence spectroscopy and FT-IR spectroscopy. UV-absorption spectrophotometry showed an increase in the absorption intensity with increasing the molecular ratios of gold nanoparticles of both sizes to BSA, it is found that the value of the binding constant is estimated to be $0.888 \times 10^{4} \mathrm{M}^{-1}$ for gold nanoparticles (40 nm)BSA complexes, and $1.16 \times 10^{4} \mathrm{M}^{-1}$ for gold nanoparticles $(60 \mathrm{~nm})$-BSA complexes. FT-IR spectroscopy analysis showed that intensities of gold nanoparticles of both sizes-BSA complexes decrease as the concentration increased.
\end{abstract}

Keywords: Protein; Gold nanoparticles; UV; Fluorescence; FT-IR

\section{Introduction}

Gold nanoparticles (AuNPs) have drawn remarkable interest in the past few years because of their potential applications in biomedicines $[1,2]$, biotechnology [3,4], electronics [5], and catalysis [6], this is due to many attractive properties, such as excellent conductivity, size-dependent properties, optical properties, non-toxicity, and their capacity for facile and highly variable functionalization. Recently, stabilization of AuNPs by a variety of biomolecules such as proteins, peptides, DNA, and carbohydrates has been of great interest due to their applications in biomedicine including diagnostics, bio-imaging and targeted drug delivery [7].

The conjugation of proteins with AuNPs not only affords stabilization of the system but, more importantly, also introduces biocompatible functionalities into these AuNPs for further biological interactions. The surface modifications of AuNPs to provide stable bimolecular functionalized AuNPs in biomedical applications have been reported by various groups $[2,6-8]$. On the other hand, antibody-antigen binding is a fundamental phenomenon in the fields of biochemistry and biology. Most bioassays are based on an antibody-antigen binding pair [9].

Serum albumin is the major protein component of blood plasma but is distributed to the interstitial fluid of the body tissues [10]. Serum albumin is capable of binding to a wide variety of drugs, and there is strong interest in this abundant protein because of its effects on drug delivery [11]. Therefore, immobilization and immunoreaction of a fundamental protein, such as serum albumin on gold NPs, is very important for bio applications.

To design an effective AuNPs-protein system for biological applications, it is necessary to study the AuNPs-protein interactions systematically. Some studies have investigated the influence of AuNP size on the conformation of cytochrome [12]; and the effect of $\mathrm{pH}$ on the conformation of BSA adsorbed on the surface of AuNPs [13-16]. Fluorescence spectroscopy [11,14], dynamic light scattering $[8,17]$, circular dichroism $[9,18]$, Fourier transform infrared spectroscopy (FTIR) [19], nuclear magnetic resonance spectroscopy [20], surface enhanced Raman scattering [21], time-correlated single photon counting spectroscopy $[13,22]$ are among a variety of techniques commonly used to characterize AuNPs-protein interactions. The combination of different techniques will give us insight into the interactions of AuNPs and proteins [16].
Bovine serum albumin (BSA) is a model globular protein which is widely used in biochemical studies [20,21]. It is composed of 583 amino acid residues containing several sulfur, oxygen and nitrogen atoms, which are generally used to stabilize the nanoparticles [22]. BSA plays a significant role in many important physiological functions, and its structure and conformation can be easily changed [23]. AuNPs-BSA bio conjugates have been used in several applications such as intracellular delivery vectors and imaging agents [24]. Fundamental studies on the interactions between AuNPs and BSA may contribute to development of optimal conditions for forming bio conjugated nanomaterials that preserve the functionality of proteins.

In this study, BSA was conjugated with AuNPs (40 and $60 \mathrm{~nm}$ ) and the interactions between them were studied by UV-visible absorption spectroscopy, fluorescence spectroscopy and Fourier transform infrared spectroscopy (FT-IR). Based on the data obtained using these techniques, the effects of BSA concentration on the stability of the AuNPs and the conformational changes of BSA upon interacting with the AuNPs are discussed, and a possible mechanism of the conjugation is proposed.

\section{Samples and Methods}

BSA and gold nanoparticles in powder form were purchased from Sigma Aldrich chemical company and used without further purifications. The data were collected using samples in the form of thin films for FT-IR measurements and liquid form for UV-VIS and fluorescence measurements.

\section{Preparation of stock solutions}

BSA was dissolved in phosphate buffer saline, at physiological $\mathrm{pH}$ 7.4 , to a concentration of $(80 \mathrm{mg} / \mathrm{ml})$, to get a final concentration of $(40 \mathrm{mg} / \mathrm{ml})$. Gold nanoparticles with molecular weight $(288.42 \mathrm{~g} / \mathrm{mol})$ was dissolved in phosphate buffer saline $(0.7622 \mathrm{mg} / \mathrm{ml})$, the phosphate

*Corresponding author: Husain Alsamamra, Physics Department, Al-Quds University, Palestine, Tel: 00972-5297166009; E-mail: hsamamra@staff.alquds.edu

Received March 01, 2018; Accepted March 20, 2018; Published March 28, 2018

Citation: Alsamamra H, Hawwarin I, Abu-Sharkh S, Abuteir M (2018) Study the Interaction between Gold Nanoparticles and Bovine Serum Albumin: Spectroscopic Approach. J Bioanal Biomed 10: 43-49. doi:10.4172/1948-593X.1000203

Copyright: () 2018 Alsamamra H, et al. This is an open-access article distributed under the terms of the Creative Commons Attribution License, which permits unrestricted use, distribution, and reproduction in any medium, provided the origina author and source are credited. 
buffer saline was at room temperature, the solution were placed on a shaker for $1 \mathrm{~h}$ in order to dissolve the gold nanoparticles powder with buffer, then it was placed in ultrasonic water path (SIBATA AU-3T) for $8 \mathrm{~h}$ to ensure that the entire amount of gold nanoparticles was completely dissolved. The solution was placed in a water path with a temperature range $37-40^{\circ} \mathrm{C}$ for $1 \mathrm{~h}$ to let the solution completely dissolved and became homogenous. The final concentrations of BSAGold nanoparticles solutions were prepared by using the following molecular ratios of BSA: Gold nanoparticles; 10:18, 10:14, 10:10, 10:6 and 10:2.

\section{UV-absorption spectrometer}

A $1 \mu \mathrm{l}$ sample of gold nanoparticles is pipetted into the end of a fiber optical cable (the receiving fiber). A second fiber optical cable (the source fiber) is then brought into contact with the liquid sample causing the liquid to bridge the gap between the fiber optical ends. The gap is controlled to both $1 \mathrm{~mm}$ and $0.2 \mathrm{~mm}$ paths. A pulsed xenon flash lamp provides the light source and a spectrophotometer utilizing a linear CCD array is used to analyze the light after passing through the sample. The absorption spectra were recorded for free BSA and for its complexes with gold nanoparticles. Repeated measurements were done for all samples.

\section{Fluorescence spectrometer}

A $2.5 \mu \mathrm{l}$ sample of gold nanoparticle is pipetted onto the end of the lower measurement pedestal (the receiving fiber). A non-reflective "bushing" attached to the arm is then brought into contact with the liquid sample causing the liquid to bridge the gap between it and the receiving fiber. The gap, or path-length, is controlled to $1 \mathrm{~mm}$. following excitation with one of the three LEDs; emitted light from the sample passing through the receiving fiber is captured by the spectrophotometer.

\section{FT-IR spectrometer}

The absorption spectra were obtained in the wave number range of $400-400 \mathrm{~cm}^{-1}$. A spectrum was taken as an average of 60 scans to increase the signal to noise ratio, and the spectral resolution was at $4 \mathrm{~cm}^{-1}$. The aperture used in this study was $8 \mathrm{~mm}$, since we found that this aperture gives best signal to noise ratio. Baseline correction, normalization and peak areas calculations were performed for all the spectra by OPUS software. The peak positions were determined using the second derivative of the spectra. The infrared spectra of BSA, Gold nanoparticles-BSA complexes were obtained in the region of 1000-1800 $\mathrm{cm}^{-1}$. The FT-IR spectrum of free BSA was acquired by subtracting the absorption spectrum of the buffer solution from the spectrum of the protein solution. For the net interaction effect, the difference spectra $\{$ (protein and gold nanoparticles solution)-(protein solution)\} were generated using the featureless region of the protein solution 1800$2200 \mathrm{~cm}^{-1}$ as an internal standard.

\section{Results and Discussion}

\section{UV-absorption spectrometer}

The absorption spectra of different ratios of gold nanoparticles (40 and $60 \mathrm{~nm}$ ) with fixed amount of BSA are displayed in Figures 1 and 2. The excitation has been done on $210 \mathrm{~nm}$ and the absorption is recorded at $278 \mathrm{~nm}$. The figures shows that the intensity of BSA increases with the increasing of gold nanoparticles percentage, and that the absorption peaks of these solutions showed moderate shifts indicating that with the addition of gold nanoparticles, the peptide

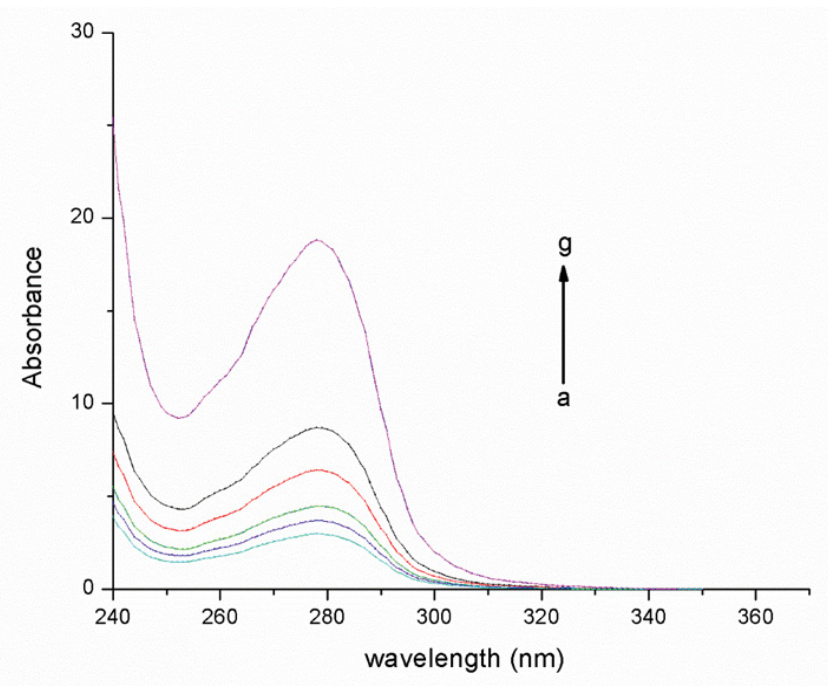

Figure 1: UV-absorbance spectra of BSA with different molar ratios of gold nanoparticles $(40 \mathrm{~nm})(\mathrm{a}=0: 10, \mathrm{~b}=2: 10, \mathrm{c}=6: 10, \mathrm{~d}=10: 10, \mathrm{e}=14: 10, \mathrm{f}=18: 10, \mathrm{~g}=$ free gold nanoparticles).

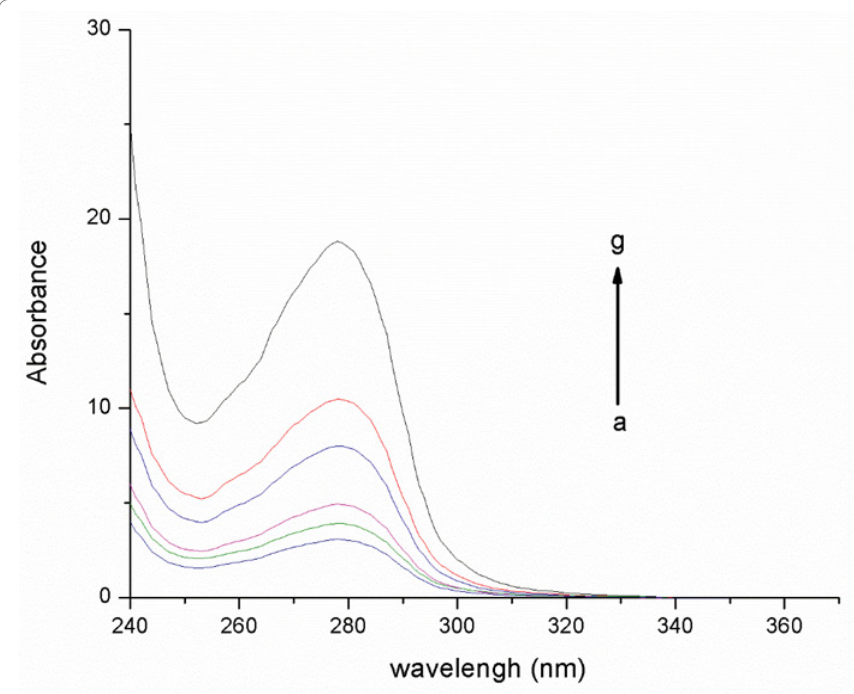

Figure 2: UV-absorbance spectra of BSA with different molar ratios of gold nanoparticles $(60 \mathrm{~nm})(\mathrm{a}=0: 10, \mathrm{~b}=2: 10, \mathrm{c}=6: 10, \mathrm{~d}=10: 10, \mathrm{e}=14: 10, \mathrm{f}=18: 10, \mathrm{~g}=$ free gold nanoparticles)

strands of BSA molecules extended more and the hydrophobicity of gold nanoparticles was decreased. The result support that the peak shifts between free BSA solution and gold nanoparticles-BSA complexes are due to the interaction between gold nanoparticles and BSA. Repeated measurements were done for all the samples showing consistent results and no significant differences were observed.

Gold nanoparticles -BSA complexes binding constants were determined using UV- spectrophotometer [20], by assuming that there is only one type of interaction between gold nanoparticles-BSA complexes, which leads to establish Equations 1 and 2 as follows:

BSA+Gold nanoparticles $\leftrightarrow$ Gold nanoparticles: BSA

$\mathrm{K}=$ [Gold nanoparticles: BSA]/[Gold nanoparticles] [BSA]

The absorption data were treated using linear double reciprocal plots based on the following equation: 


$$
1 / A-A_{0}=1 / A_{\infty}-A_{0}+1 / K\left[A_{\infty}-A_{0}\right] .1 / L
$$

Where $\mathrm{A}_{0}$ corresponds to the initial absorption of protein at 280 $\mathrm{nm}$ in the absence of ligand, $\mathrm{A}_{\infty}$ is the final absorption of the ligated protein, and $\mathrm{A}$ is the recorded absorption at different gold nanoparticles concentrations $(\mathrm{L})$. The double reciprocal plot of $1 /\left(\mathrm{A}-\mathrm{A}_{0}\right) v s .1 / \mathrm{L}$ is linear as it shown in Figures 3 and 4.

The binding constant $(\mathrm{K})$ can be estimated from the ratio of the intercept to the slope to be $\left(0.888 \times 10^{4} \mathrm{M}^{-1}\right)$ for gold nanoparticles $(40 \mathrm{~nm})$-BSA complexes, and $\left(1.16 \times 10^{4} \mathrm{M}^{-1}\right)$ for gold nanoparticles $(60 \mathrm{~nm})$-BSA complexes. The value obtained is indicative a weak gold nanoparticles protein interaction with respect to the other drug-BSA complexes with binding constant in the range of $10^{5}$ and $10^{6} \mathrm{M}^{-1}$ [22].

\section{Fluorescence spectrophotometer}

In this work, BSA-Gold nanoparticles complexes excitation wavelength at $360 \mathrm{~nm}$ was used, and the observed wavelength emission was at $439 \mathrm{~nm}$. The fluorescence sensor is based on intramolecular

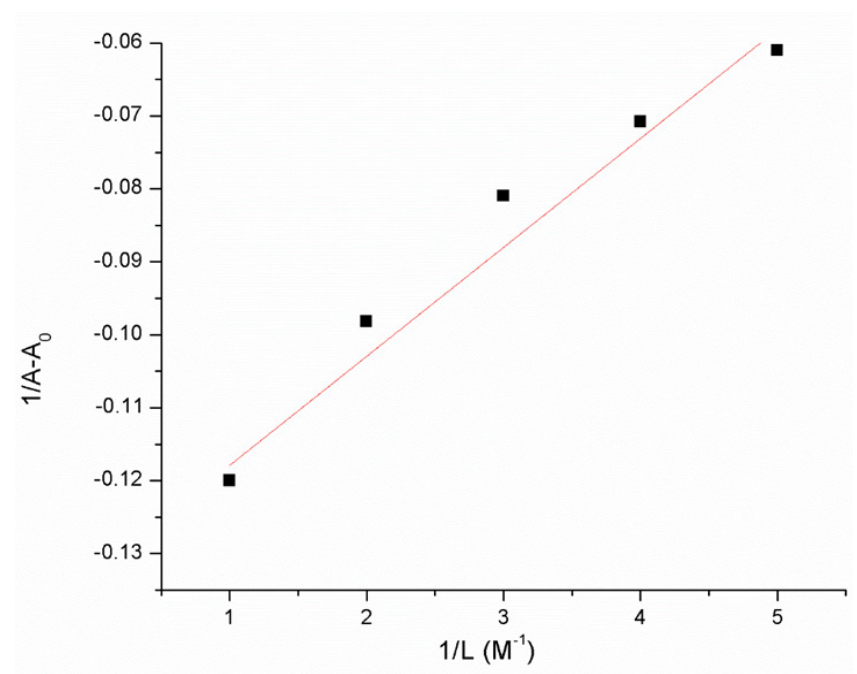

Figure 3: The plot of $1 / \mathrm{A}-\mathrm{A}_{0}$ vs. $1 / \mathrm{L}$ for $\mathrm{BSA}$ with different concentrations of gold nanoparticles 40 .

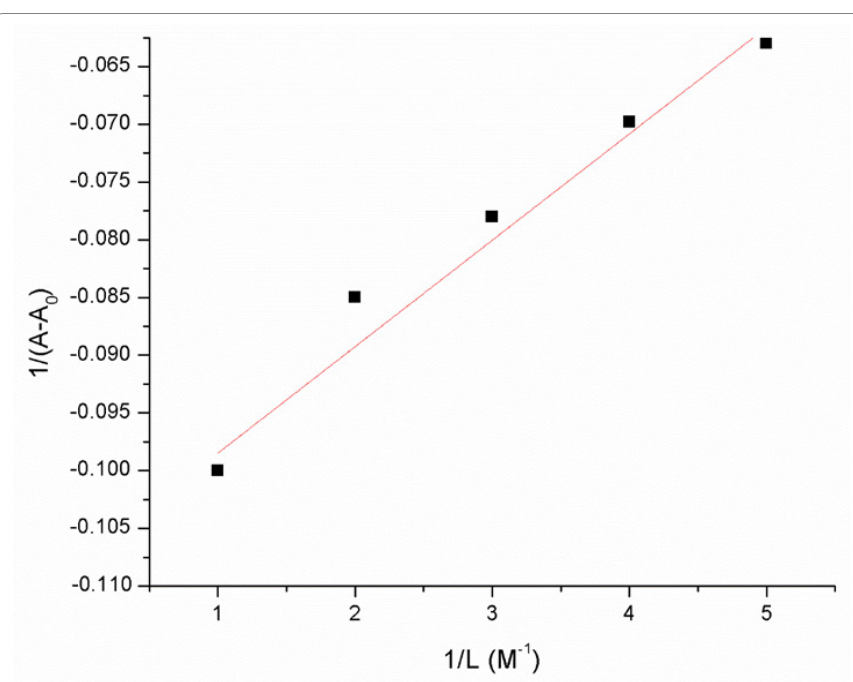

Figure 4: The plot of $1 / A-A_{0}$ vs. 1/L for BSA with different concentrations of gold nanoparticles $60 \mathrm{~nm}$. charge transfer (ICT), which is highly sensitive to the polarity of microenvironment. Therefore, it is expected to act as fluorescent probe for some biochemical systems like proteins.

The fluorescence quenching spectra of BSA at various percentages of gold nanoparticles ( $40 \mathrm{~nm}$ and $60 \mathrm{~nm}$ ) are shown in Figures 5 and 6. Obviously from the results, the fluorescence intensity of BSA gradually decreased while the peak position shows little change upon increasing the percentage of gold nanoparticles, indicating that gold nanoparticles binds to BSA. Under the same condition, no fluorescence of gold nanoparticles was observed that indicates gold nanoparticles could quench the auto fluorescence of BSA and the interaction between gold nanoparticles and BSA exists.

Fluorescence quenching can be defined as a bimolecular process that reduces the fluorescence intensity without changing the fluorescence emission spectrum; it can result from transient excited-

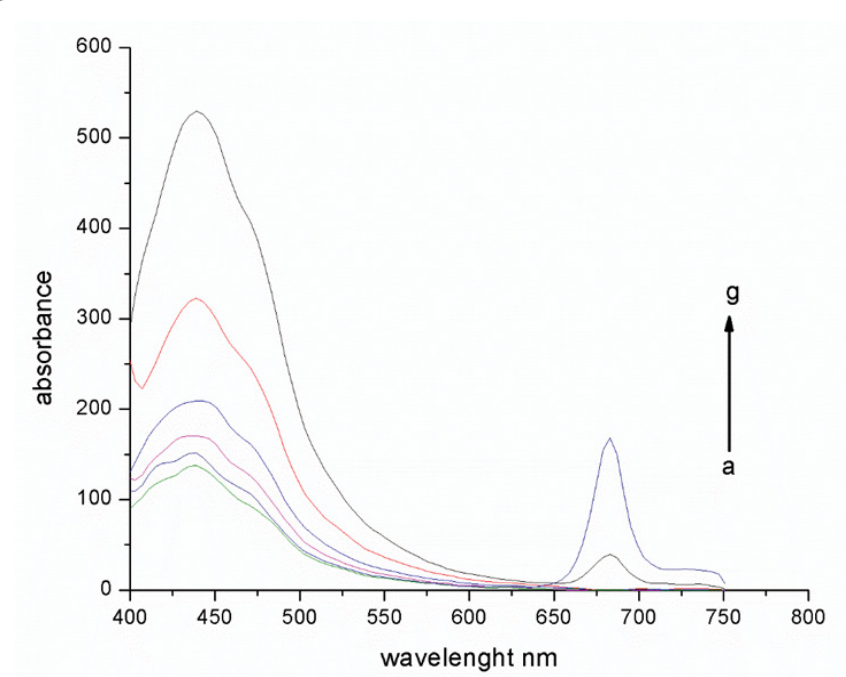

Figure 5: Fluorescence absorption spectra of BSA in the absence and presence of gold nanoparticles $40 \mathrm{~nm}$ in these ratios $(a=0: 10, b=2: 10, c=6: 10$, $d=10: 10, e=14: 10, f=18: 10, g=$ free gold nanoparticles).

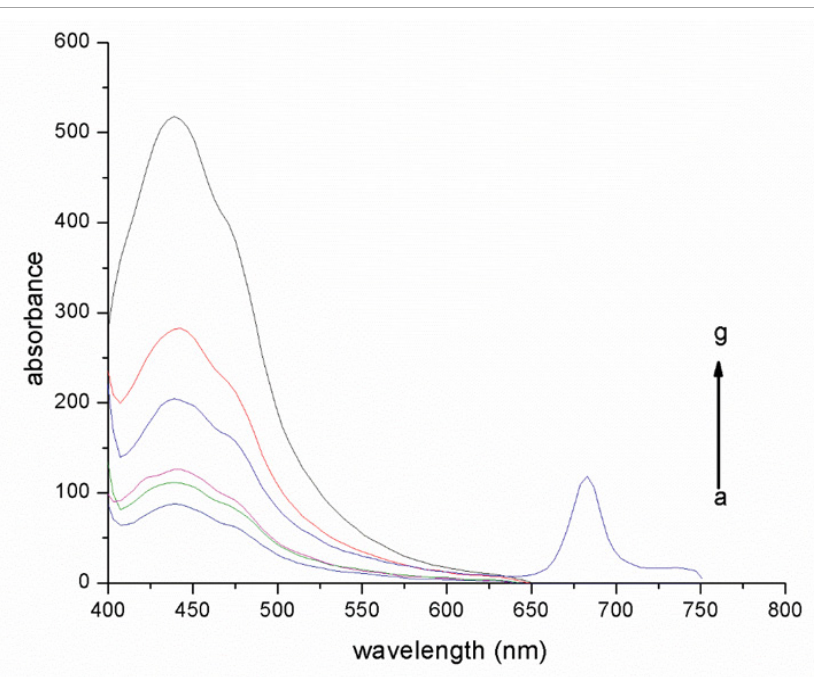

Figure 6: Fluorescence absorption spectra of BSA in the absence and presence of gold nanoparticles $60 \mathrm{~nm}$ in these ratios $(a=0: 10, b=2: 10, c=6: 10$, $d=10: 10, e=14: 10, f=18: 10, g=$ free gold nanoparticles). 
Citation: Alsamamra H, Hawwarin I, Abu-Sharkh S, Abuteir M (2018) Study the Interaction between Gold Nanoparticles and Bovine Serum Albumin: Spectroscopic Approach. J Bioanal Biomed 10: 43-49. doi:10.4172/1948-593X.1000203

state interactions (collisional quenching) or from formation of nonfluorescent ground-state species.

For dynamic quenching, the decrease in fluorescence intensity is described by Stern-Volmer equation [20].

$$
\mathrm{F}_{0} / \mathrm{F}=1+\mathrm{K}_{s v}[\mathrm{~L}]=1+\mathrm{k}_{\mathrm{q}} \tau_{0}[\mathrm{~L}]
$$

In this expression $\mathrm{F}$ and $\mathrm{F}_{0}$ are the fluorescence intensities with and without quencher, $\mathrm{K}_{\mathrm{sv}}$ is the Stern-Volmer quenching constant, $\mathrm{K}_{\mathrm{q}}$ is the bimolecular quenching constant, $\tau_{0}$ is average lifetime of the biomolecule without quencher, and (L) is the quencher concentration. The Stern-Volmer quenching constant $\mathrm{K}_{\mathrm{sv}}$ indicates the sensitivity of the fluorophore to a quencher.

The Stern-Volmer quenching constant $\mathrm{K}_{\mathrm{sv}}$ was obtained by the slope of the curves obtained in Figures 7 and 8 , and its value equals $(2.17 \times$ $10^{2} \mathrm{~L} \mathrm{~mol}^{-1}$ ) for gold nanoparticles $40 \mathrm{~nm}$-BSA complexes. From the equation the value of $\mathrm{K}_{\mathrm{sv}}=\mathrm{Kq}^{*} \tau_{0}$, from which we can calculate the value of $\mathrm{K}_{\mathrm{q}}$ using the fluorescence life time of $10^{-8} \mathrm{~s}$ for BSA [16], to obtain $\mathrm{K}_{\mathrm{q}}$ value of $\left(2.17 \times 10^{10} \mathrm{Lmol}^{-1} \mathrm{~s}^{-1}\right)$ for gold nanoparticles-BSA complexes.

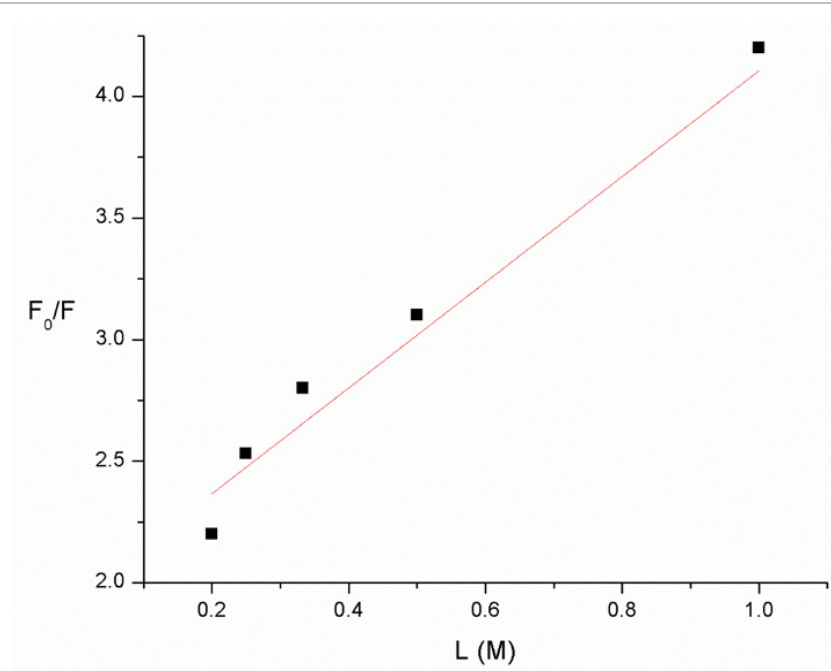

Figure 7: The Stern Volmer plot for gold nanoparticles 40nm -BSA complexes.

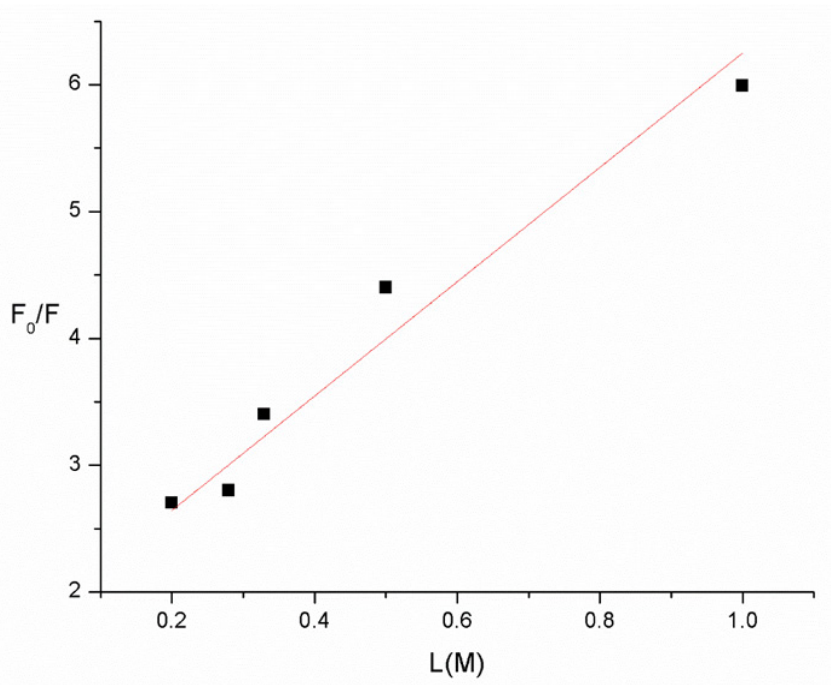

Figure 8: The Stern Volmer plot for gold nanoparticles $60 \mathrm{~nm}$-BSA complexes.
The value of $\mathrm{K}_{\mathrm{sv}}$ for gold nanoparticles $60 \mathrm{~nm}$-BSA complexes (4.5 $\left.\times 10^{2} \mathrm{Lmol}^{-1}\right)$. However, the value of $\mathrm{K}_{\mathrm{q}}\left(4.5 \times 10^{10} \mathrm{Lmol}^{-1} \mathrm{~s}^{-1}\right)$ which is larger than the maximum dynamic quenching constant for various quenchers with biopolymer $\left(2 \times 10^{10} \mathrm{Lmol}^{-1} \mathrm{~s}^{-1}\right)$. This implies that the quenching is not initiated by dynamic collision but from formation of a complex, so static quenching is dominant.

For static quenching, the following equation is used to determine the binding constant between BSA and gold nanoparticles.

$$
1 /\left(\mathrm{F}_{0}-\mathrm{F}\right)=1 / \mathrm{F}_{0} \mathrm{~K}(\mathrm{~L})+1 / \mathrm{F}_{0}
$$

Where $\mathrm{K}$ is the binding constant of gold nanoparticles with BSA, and can be calculated by plotting $1 /\left(\mathrm{F}_{0}-\mathrm{F}\right) v s .1 / \mathrm{L}$. As shown in Figures 8 and 9 , the value of $\mathrm{K}$ equals the ratio of the intercept to the slope. The obtained value of $\mathrm{K}$ equals $\left(0.92 \times 10^{4} \mathrm{M}^{-1}, 1.3 \times 10^{4} \mathrm{M}^{-1}\right)$ respectively from Figures 9 and 10 which agree well with the value obtained earlier UV spectroscopy and supports the effective role of static quenching.

The acting forces between a small molecule substance and macromolecule mainly include hydrogen bond, Van der Waals forces',

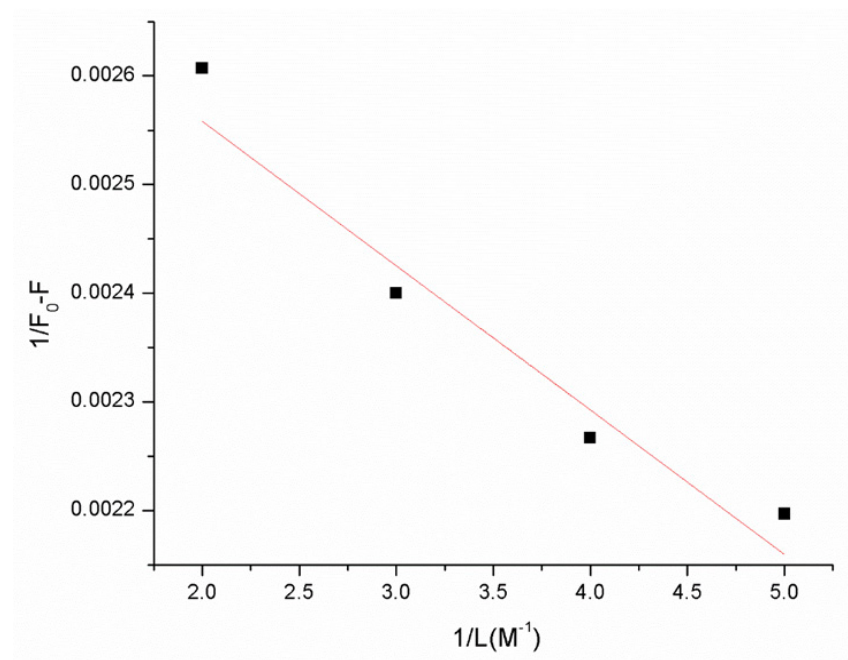

Figure 9: The plot of $1 / \mathrm{F}_{0}-\mathrm{F}$ vs. $(1 / \mathrm{L}) \times 10^{4}$ for gold nanoparticles $40 \mathrm{~nm}-\mathrm{BSA}$ complexes.

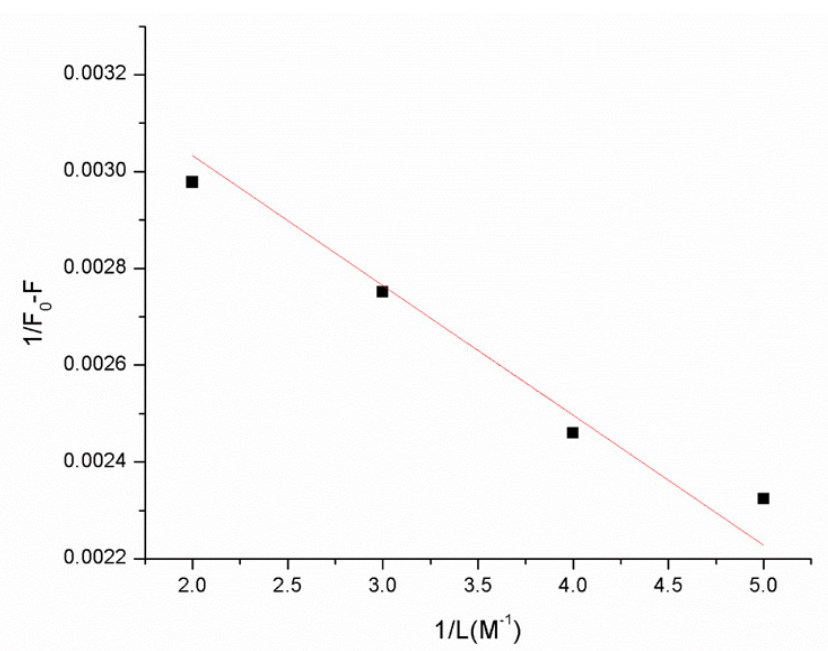

Figure 10: The plot of $1 / \mathrm{F}_{0}-\mathrm{F}$ vs. $(1 / \mathrm{L}) \times 10^{4}$ for gold nanoparticles $60 \mathrm{~nm}-\mathrm{BSA}$ complexes. 
electrostatic force and hydrophobic interaction force. It was more likely that hydrophobic and electrostatic interactions were involved in the binding process.

However, gold nanoparticles might be largely unionized under the experimental conditions, as expected from its structure. Hence, electrostatic interaction could be precluded from the binding process. Thus, the binding of gold nanoparticles to BSA includes the hydrophobic interaction. Hydrophobic interaction is mostly an entropic effect originating from the disruption of highly dynamic hydrogen bonds between molecules of liquid water by the nonpolar solutes. Minimizing the number of hydrophobic side chains exposed to water is the principal driving force behind the folding process. Formation of hydrogen bonds within the protein stabilizes protein structure [23].

\section{FT-IR Spectroscopy}

FT-IR spectroscopy provides information about secondary content of proteins; this information arises from the amide band which is a result from the vibrations of the groups around the peptide bonds of proteins. Changes in hydrogen bonding involves in the peptide linkages would occur, this results in changes of vibrational frequency of the different amide modes when the binding between drugs and globular protein like BSA occurs.

As shown in Figure 11, the infrared spectrum of protein is characterized by a set of absorption the amide region and the $\mathrm{C}-\mathrm{H}$ region. The modes most widely used in protein structural studies are amide I, amide II and amide III.

Amide I band ranging from 1700 to $1600 \mathrm{~cm}^{-1}$ and arises principally from the $\mathrm{C}=\mathrm{O}$ stretching. Amide II band is primarily $\mathrm{N}-\mathrm{H}$ bending with a contribution from $\mathrm{C}-\mathrm{N}$ stretching vibrations, amide II ranging from 1600-1480 $\mathrm{cm}^{-1}$. Amide III band ranging from 1330-1220 $\mathrm{cm}^{-1}$ which is due to the $\mathrm{C}-\mathrm{N}$ stretching mode coupled to the in-plane $\mathrm{N}-\mathrm{H}$ bending mode. This absorption is normally weak.

As Figures 12 and 13 provides, it is obviously seen as gold nanoparticles ratio were increased the intensities of the amide I, amide II and amide III bands decreased further in the spectra of all gold nanoparticles BSA complexes. The reduction in the intensity of the three amide bands is related to the gold nanoparticles BSA interaction.

In Table 1 the peak positions of BSA with different ratios of gold nanoparticles (40 $\mathrm{nm}$ ) are listed. For gold nanoparticles ( $40 \mathrm{~nm}$ )-BSA interaction the amide bands of BSA infrared spectrum shifted, for amide I band the peak positions have shifted as follows: $1621 \mathrm{~cm}^{-1}$ to $1629 \mathrm{~cm}^{1}, 1654 \mathrm{~cm}^{-1}$ to $1658 \mathrm{~cm}^{-1}$. In amide II the peak positions have shifted as follows: $1513 \mathrm{~cm}^{-1}$ to $1523 \mathrm{~cm}^{-1}$ and $1579 \mathrm{~cm}^{-1}$ to $1583 \mathrm{~cm}^{-1}$, in addition new peaks have been appeared at high molecular ratios of gold nanoparticles at $1547 \mathrm{~cm}^{-1}$ and 1569 . In amide III region the peak positions are also have been shifted as the following order: $1242 \mathrm{~cm}^{-1}$ to $1241 \mathrm{~cm}^{-1}, 1314 \mathrm{~cm}^{-1}$ to $1315 \mathrm{~cm}^{-1}, 1339 \mathrm{~cm}^{-1}$ to $1335 \mathrm{~cm}^{-1}$ and 1366 $\mathrm{cm}^{-1}$ to $1361 \mathrm{~cm}^{-1}$.

In Table 2 the peak positions of BSA with different ratios of gold nanoparticles $(60 \mathrm{~nm})$ are listed. For gold nanoparticles $(60 \mathrm{~nm})$-BSA interaction the amide bands of BSA infrared spectrum shifted as listed in the table, for amide I band the peak positions have shifted as follows: $1621 \mathrm{~cm}^{-1}$ to $1626 \mathrm{~cm}^{1}, 1654 \mathrm{~cm}^{-1}$ to $1655 \mathrm{~cm}^{-1}$. In amide II the peak positions have shifted as follows: $1513 \mathrm{~cm}^{-1}$ to $1516 \mathrm{~cm}^{-1}$ and 1579 $\mathrm{cm}^{-1}$ to $1581 \mathrm{~cm}^{-1}$, in addition new peaks have been appeared at high molecular ratios of gold nanoparticles at $1545 \mathrm{~cm}^{-1}$ and 1557. In amide III region the peak positions are also have been shifted as the following order: $1242 \mathrm{~cm}^{-1}$ to $1241 \mathrm{~cm}^{-1}, 1314$ dos not change, $1339 \mathrm{~cm}^{-1}$ to 1332 $\mathrm{cm}^{-1}$ and $1366 \mathrm{~cm}^{-1}$ to $1357 \mathrm{~cm}^{-1}$.

To summarize, the binding of gold nanoparticles of both sizes to BSA has been investigated by UV-absorption spectroscopy, fluorescence spectrometry and by FT-IR spectroscopy. From the UV and fluorescence investigations, we determined the values for the binding constants and the quenching constant. The FT-IR analysis reveals intensity reduction.

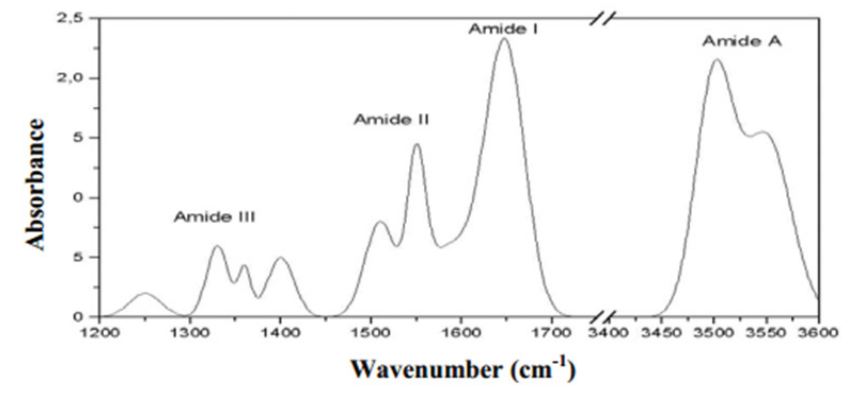

Figure 11: Sample spectrum showing the three relevant regions for determination of protein secondary structure. Amide I $\left(1700-160 \mathrm{~cm}^{-1}\right)$, amide II (160-1480 $\left.\mathrm{cm}^{-1}\right)$, amide III $\left(1330-1220 \mathrm{~cm}^{-1}\right)$.

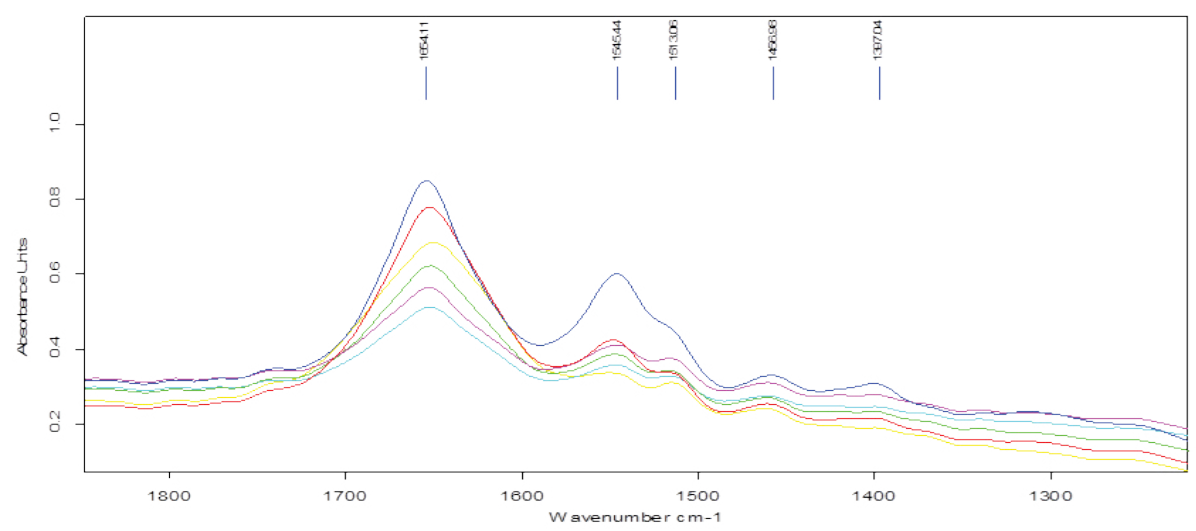

Figure 12: The spectrum of Gold nanoparticles $40 \mathrm{~nm}$-BSA complexes with different percentage of gold nanoparticles. 
Citation: Alsamamra H, Hawwarin I, Abu-Sharkh S, Abuteir M (2018) Study the Interaction between Gold Nanoparticles and Bovine Serum Albumin: Spectroscopic Approach. J Bioanal Biomed 10: 43-49. doi:10.4172/1948-593X.1000203

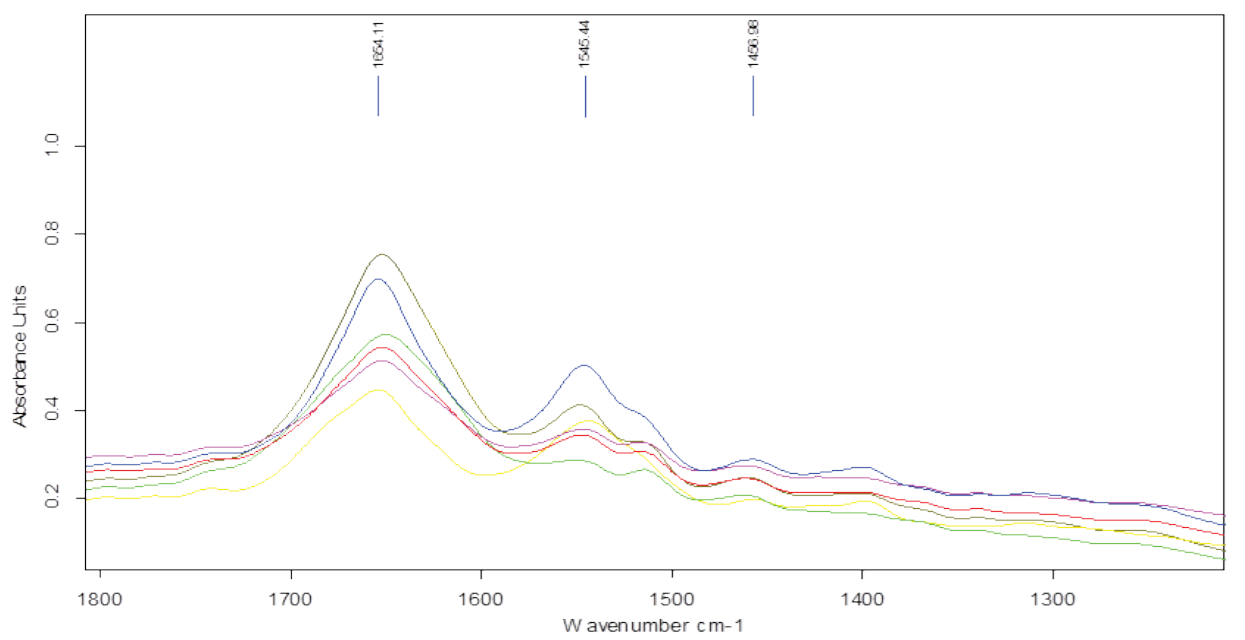

Figure 13: The spectrum of Gold nanoparticles $60 \mathrm{~nm}-\mathrm{BSA}$ complexes with different percentage of gold nanoparticles.

\begin{tabular}{|c|c|c|c|c|c|c|}
\hline \multirow{2}{*}{ Bands } & \multirow[t]{2}{*}{ Free BSA } & $\begin{array}{c}\text { BSA - gold } \\
\text { nanoparticles }\end{array}$ & $\begin{array}{c}\text { BSA - gold } \\
\text { nanoparticles }\end{array}$ & BSA - gold nanoparticles & $\begin{array}{c}\text { BSA - gold } \\
\text { nanoparticles }\end{array}$ & $\begin{array}{c}\text { BSA- gold } \\
\text { nanoparticles }\end{array}$ \\
\hline & & 01:01 & 01:02 & 01:03 & 01:04 & 01:05 \\
\hline amide I & 1621 & 1622 & 1622 & 1628 & 1629 & 1629 \\
\hline$(1700-1600)$ & 1654 & 1654 & 1655 & 1657 & 1658 & 1658 \\
\hline amide II & 1513 & 1513 & 1517 & 1521 & 1521 & 1523 \\
\hline \multirow[t]{2}{*}{$(1600-1480)$} & 1545 & 1548 & 1552 & 1559 & 1563 & 1569 \\
\hline & 1579 & 1578 & 1578 & 1782 & 1782 & 1783 \\
\hline amide III & 1242 & 1242 & 1241 & 1243 & 1241 & 1241 \\
\hline \multirow[t]{3}{*}{$(1330-1220)$} & 1314 & 1314 & 1341 & 1314 & 1316 & 1315 \\
\hline & 1339 & 1339 & 1338 & 1337 & 1335 & 1335 \\
\hline & 1366 & 1365 & 1364 & 1364 & 1362 & 1361 \\
\hline
\end{tabular}

Table 1: Band assignment in the absorbance spectra of BSA with different gold nanoparticles (40 $\mathrm{nm}$ ) molecular ratios for amide I, amide II, and amide III regions.

\begin{tabular}{|c|c|c|c|c|c|c|}
\hline Bands & Free BSA & $\begin{array}{c}\text { BSA - gold } \\
\text { nanoparticles } \\
1: 1\end{array}$ & $\begin{array}{c}\text { BSA - gold } \\
\text { nanoparticles } \\
1: 2\end{array}$ & $\begin{array}{c}\text { BSA - gold } \\
\text { nanoparticles } \\
1: 3\end{array}$ & $\begin{array}{c}\text { BSA - gold } \\
\text { nanoparticles } \\
1: 4\end{array}$ & $\begin{array}{c}\text { BSA - gold } \\
\text { nanoparticles } \\
1: 5\end{array}$ \\
\hline $\begin{array}{c}\text { amide I } \\
(1700-1600)\end{array}$ & $\begin{array}{l}1621 \\
1654\end{array}$ & $\begin{array}{l}1621 \\
1654\end{array}$ & $\begin{array}{l}1622 \\
1655\end{array}$ & $\begin{array}{l}1623 \\
1655\end{array}$ & $\begin{array}{l}1623 \\
1655\end{array}$ & $\begin{array}{l}1626 \\
1655\end{array}$ \\
\hline $\begin{array}{c}\text { amide II } \\
(1600-1480)\end{array}$ & $\begin{array}{l}1513 \\
1545 \\
1579\end{array}$ & $\begin{array}{l}1513 \\
1547 \\
1578\end{array}$ & $\begin{array}{l}1514 \\
1551 \\
1578\end{array}$ & $\begin{array}{l}1514 \\
1552 \\
1779\end{array}$ & $\begin{array}{l}1515 \\
1554 \\
1781\end{array}$ & $\begin{array}{l}1516 \\
1557 \\
1781\end{array}$ \\
\hline $\begin{array}{c}\text { amide III } \\
(1330-1220)\end{array}$ & $\begin{array}{l}1242 \\
1314 \\
1339 \\
1366\end{array}$ & $\begin{array}{c}1242 \\
1314 \\
1339 \\
13654\end{array}$ & $\begin{array}{l}1241 \\
1314 \\
1338 \\
1361\end{array}$ & $\begin{array}{l}1242 \\
1314 \\
1337 \\
1360\end{array}$ & $\begin{array}{l}1241 \\
1314 \\
1335 \\
1359\end{array}$ & $\begin{array}{l}1241 \\
1314 \\
1332 \\
1357\end{array}$ \\
\hline
\end{tabular}

Table 2: Band assignment in the absorbance spectra of BSA with different gold nanoparticles (60 nm) molecular ratios for amide I, amide II, and amide III regions.

\section{Conclusion}

BSA plays a significant role in many important physiological functions, and its structure and conformation can be easily changed. Gold nanoparticles can easily form conjugates with proteins through either covalent bonds or physical interactions, and these conjugates have been widely applied in biomedical fields, including diagnostics, bioimaging and targeted drug delivery. In order to design an effective gold nanoparticles-protein system for biological applications, it is necessary to study the gold nanoparticles-BSA interactions systematically. This is important for the application of the gold nanoparticles-BSA bio conjugates in nanobiosensors, disease diagnostics, drug delivery, biological labeling and imaging, and where biological activity is required.

\section{References}

1. Zhou X, Zhang X, Yu X, Zha X, Fu Q, et al. (2008) The effect of conjugation to gold nanoparticles on the ability of low molecular weight chitosan to transfer DNA vaccine. Biomaterials 29: 111-117.

2. Liu T, Tang J, Jiang L (2004) The enhancement effect of gold nanoparticles as a surface modifier on DNA sensor sensitivity. Biochem Biophys Res Commun 313: 3-7.

3. Medley CD, Smith JE, Tang Z, Wu Y, Bamrungsap S (2008) Gold nanoparticlebased colorimetric assay for the direct detection of cancerous cells. Anal Chem 80: 1067-1072.

4. Scampicchio M, Arecchi A, Mannino S (2009) Optical nanoprobes based on gold nanoparticles for sugar determination. Nanotechnology 20: 135501 135505.

5. Labande A, Ruiz J, Astruc D (2002) Supramolecular gold nanoparticles for the 
Citation: Alsamamra H, Hawwarin I, Abu-Sharkh S, Abuteir M (2018) Study the Interaction between Gold Nanoparticles and Bovine Serum Albumin: Spectroscopic Approach. J Bioanal Biomed 10: 43-49. doi:10.4172/1948-593X.1000203

redox recognition of oxoanions: syntheses, titrations, stereoelectronic effects, and selectivity. J Am Chem Soc 124: 1782-1789.

6. Liu Z, Hu P, Alavi A (2002) Catalytic role of gold in gold-based catalysts: a density functional theory study on the $\mathrm{CO}$ oxidation on gold. J Am Chem Soc 124: $14770-14779$

7. Hussain ST, Iqbal M, Mazhar M (2009) Size control synthesis of starch cappedgold nanoparticles. J Nanoparticle Res 11: 1383-1391.

8. Niemeyer CM (2001) Nanoparticles, proteins, and nucleic acids: Biotechnology meets materials science. Angew Chem Int Ed 40: 4128-4158.

9. Johnsona SR, Evans SD, Mahonb SW, A Ulmanc A (1997) Synthesis and characterisation of surfactant-stabilised gold nanoparticles, Supramol Sci 4: 329-333.

10. De Roe C, Courtoy PJ, Baudhuin P (1987) A model of protein-colloidal gold interactions. J Histochem Cytochem 35: 1191-1198.

11. Pramanik S, Banerjee P, Sarkar A (2008) Size-dependent interaction of gold nanoparticles with transport protein: A spectroscopic study. J Lumines 128: 1969-1974.

12. Shang L, Wang $Y Z$, Jiang JG (2007) pH-dependent protein conformational changes in albumin: Gold nanoparticle bio-conjugates: A spectroscopic study. Langmuir 23: 2714-2721.

13. Pan B, Cui D, Xu P (2007) Study on interaction between gold nanorod and bovine serum albumin. Colloid Surface A 295: 217-222.

14. Jans H, Liu X, Austin L, Maes G, Huo Q (2009) Dynamic light scattering as a powerful tool for gold nanoparticle bioconjugation and biomolecular binding studies. Anal Chem 81: 9425-9432.

15. Wangoo N, Suri C R, Shekhawat G (2008) Interaction of gold nanoparticles with protein: A spectroscopic study to monitor protein conformational changes Appl Phys Lett 92: 133104.

16. Naveenraj S, Anandan S, Kathiravan A (2010) The interaction of sonochemically synthesized gold nanoparticles with serum albumins. J Pharm Biomed Anal 53: 804-810.

17. Zhang YZ, Dai J, Xiang X, Li WW, Liu Y (2010) Studies on the interaction between benzidine and bovine serum albumin by spectroscopic methods. Mol Biol Rep 37: 1541-1549.

18. Bi S, Ding L, Tian Y, Song D, Zhou X, et al. (2004) Investigation of the interaction between flavonoids and human serum albumin. J Mol Struct 703: 37-45.

19. Cui $Y$ (2001) Nanowire nanosensors for highly sensitive and selective detection of biological and chemical species. Science 293: 1289-1292.

20. Surewicz WK, Mantsch HH, Chapman D (1993) Determination of protein secondary structure by Fourier transform infrared spectroscopy: A critical assessment. Biochemistry 32: 389-394.

21. Brewer SH, Glomm WR, Johnson MC, Knag MK, Franzen S (2005) Probing BSA binding to citrate-coated gold nanoparticles and surfaces. Langmuir 21: 9303-9307.

22. Gao D, Tian Y, Bi S, Chen Y, Yu A, et al. (2005) Studies on the interaction of colloidal gold and serum albumins by spectral methods. Spectrochim Acta Part A 62: 1203-1208.

23. Ojha B, Das G (2010) The interaction of 5-(alkoxy) naphthalen-1-amine with bovine serum albumin and its effect on the conformation of protein. $J$ Phys Chem B 114: 3979-3986.

24. Bourassa $P$, Kanakis CD, Tarantilis P, Pollissiou MG, Tajmir-Riahi HA (2010) Resveratrol, genistein, and curcumin bind bovine serum albumin. J Phys Chem B 114: 3348-3354. 